DOI 10.22363/2313-2310-2019-27-1-17-28

Research article

UDC 528.88:631.459

\title{
Assessment of soil erosion of Burundi using remote sensing and GIS by RUSLE model
}

\author{
Gilbert Nijimbere, Christian Riveros Lizana
}

\author{
Kuban State Agrarian University named after I.T. Trubilin \\ 13 Kalinina St., Krasnodar, 350044, Russian Federation
}

\begin{abstract}
This present work is the results of study on water erosion in Burundi, a landlocked country amid the African Great Lakes region where East and Central Africa converge. The agriculture is developed in areas where the slopes is very steep and some factors such as land-use methods weaken soils and lead to water erosion and the results in soil degradation rendering it infertile. Production on this way is becoming insufficient for the rapidly growing of population. The extension of cultivated land often not linked to anti-erosion measures exposes the soil to intense erosion. The results get it of processing satellite images (Landsat 8) allowed to identify the main places where erosion is very severe. Lost soil was estimated by the RUSLE method and using four raster images corresponding to factors related to precipitation, soil erodibility, topography, slope length and vegetation cover. The results obtained allow the identification of areas around all the country where the interventions of government and environment protection institutions are necessary to limit the processes of soil degradation.
\end{abstract}

Keywords: Burundi; soil erosion; land use; RUSLE; soil degradation; soil classification; agriculture protection

\section{Introduction}

Burundi, a totally landlocked country, lies between $2^{\circ} 45^{\prime}$ and $4^{\circ} 28^{\prime}$ south latitude, and $28^{\circ} 50^{\prime}$ and $30^{\circ} 50^{\prime}$ east longitude. It shares borders with Rwanda in the north, the United Republic of Tanzania in the east and south, and the Democratic Republic of Congo in the west, where Lake Tanganyika is located (Figure 1).

Burundi has an area of $27,834 \mathrm{~km}^{2}$. In 2002, the cultivated area was 1,351,000 ha, including 986,000 ha of arable land and 365,000 ha of permanent crops [1]. From morphological point, the country includes most of the reliefs of East Africa. The landscape of the country is varied, at altitudes between $775 \mathrm{~m}$ and $2,670 \mathrm{~m}$.

The mountains of the Congo-Nile Ridge border the east part of the Lake Tanganyika while a multitude of hills dissect the Nilotic side of the ridge. Highlands surround the center and the east of the country. The distribution of rainfall

(C) Nijimbere G., Riveros Lizana C., 2019

(c) (i) This work is licensed under a Creative Commons Attribution 4.0 International License https://creativecommons.org/licenses/by/4.0/ 
in the year is characterized by alternating dry season - rainy season. The rains fall from September to April and the maximum precipitation is reached in April. From mid-December to mid-February, the rains decrease to few weeks [8]. The most important soil types are caolisols (dominant soils), recent tropical soils, tropical brown soils, tropical black soils, recent textural soils, raw mineral soils and organic soils [1].

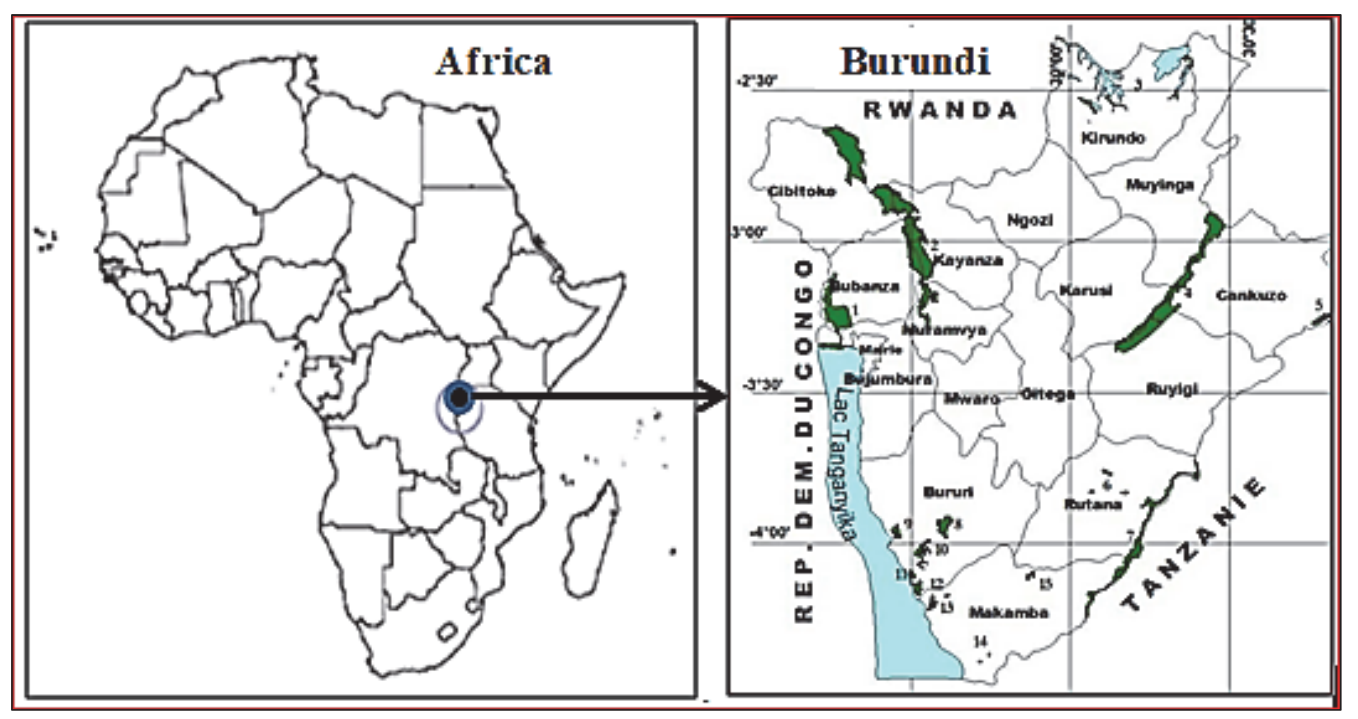

Figure 1. Location of Burundi (maps based on administrative boundaries)

Soil erosion can be defined as the detachment and translocation of soil particles by moving them by water or wind from their original location to new deposition areas [13]. Water erosion in many regions in Burundi is mainly due to the effect of LS (slope index: degree and length of slope) in the meaning of the unfortunate consequences for agriculture, namely: the destruction of the soil structure, the tearing up and sedimentation in lakes or rivers linked to constituent particles, the losses of water and elements useful for the growth of plants are the more revenues. Soil erosion in real terms endangers food security, soil subsistence productivity, water storage area, surface water quality, scenic beauty and natural ecological balance. His solution lies in adapting conservation practices [11].

The land use rate is on average $72 \%$ for the whole country [12]. This is due to the rapid demographic growth observed in the country where the annual growth is $3 \%$. Overexploitation of plant resources consists of illegal cutting, sawing, irrational picking, and decortication of trunks and carbonization either for energy purposes or extension of houses of habitations. The exploitation of minerals weakens the soil and makes it vulnerable to rain erosion.

These practices significantly reduce some ecosystems and many species that are useful in soil conservation [14]. In addition, clearing for agricultural purposes continues to be a major cause of deforestation. The average farm size of a household with 6 children is now 0,5 ha. As a result of the gradual decline in the size of the agricultural land and the loss of its fertility, the population tends to resort to forest areas in search of new agricultural lands that are still fertile [9]. 


\section{Methodology and parameter estimation}

The RUSLE model was selected and applied in the study area, a land cover map is required with land use generated by remote sensing images (Landsat 8), land management practices, land types and properties. The raster precipitation prepared base map was then used for the extraction of study area from satellite image (Satellite TRMM_3A12) and Carto DEM (digital elevation model obtained from ASTER GDEM v2).

RUSLE is the best available practical erosion prediction model that can be regional level. The model use parameters such as slope, aspect, etc. derived from DEM and LULC (land use land cover) from satellite images it can be integrated with RUSLE.

RUSLE uses the same empirical principles as the USLE but includes improved rainfall erosivity factor $R$, incorporation of the influence of profile convexity and concavity using segmentation of irregular slopes and empirical equation for processing slope factor FS [2].

The RUSLE empirical model combines the factors that affect the magnitude of erosion and is as follows:

$$
A=R * K * L * S * C * P
$$

where $A$ - rate of soil loss $\left(\mathrm{T} \cdot \mathrm{ha}^{-1} \cdot \mathrm{year}^{-1}\right) ; R$ - erosivity of the rain $\left(\mathrm{MJ} \cdot \mathrm{mm} \cdot(\mathrm{ha} \cdot \mathrm{h})^{-1}\right)$; $K$ - erodibility of the soil $\left(\mathrm{T} \cdot \mathrm{ha} \cdot \mathrm{h} \cdot(\mathrm{MJ} \cdot \mathrm{mm} \cdot \mathrm{ha})^{-1}\right) ; L S$ - topographic factor integrating slope and slope length; $C$ - soil protection factor by vegetation cover; $P$ factor of soil conservation practice.

The superposition of the four thematic maps considered the parameters of the USLE under GIS allows the obtaining of the erosion map. The erosion potential in T/ha. To arrive at the thematic map containing the data on the water erosion, the diagram (Figure 2) includes the steps to follow during the data processing.

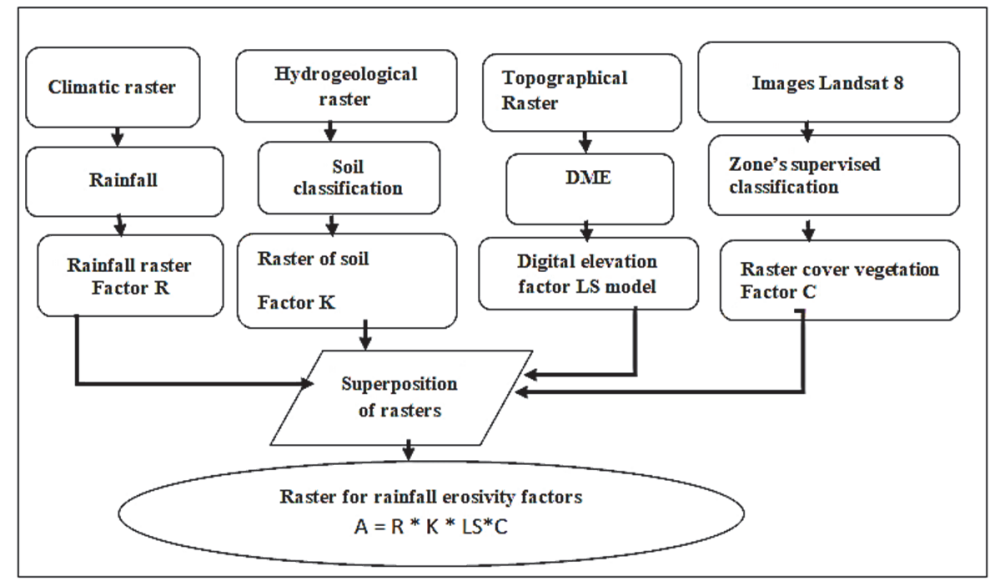

Figure 2. Steps of processing data

Rainfall Erosivity Factor $(\boldsymbol{R})$. The rainfall erosivity factor $(R)$ reflects the effect of rainfall intensity on soil erosion. The value of rainfall erosivity factor used in RUSLE must quantify the effect of raindrop impact and must also reflect the amount and rate of runoff likely to be associated with the rainfall [3]. 


$$
R=117.6 * 1.00105^{\mathrm{MAR}} \text { for }<2000 \mathrm{~mm} \text {, }
$$

where $R$ - rainfall erosivity factor $\left(\mathrm{MJ} \cdot \mathrm{mm} \cdot(\mathrm{ha} \cdot \mathrm{h})^{-1}\right) ; M A R-$ mean annual rainfall $(\mathrm{mm})$.

Soil Erodibility Factor $(\boldsymbol{K})$. The soil erodibility factor $(K)$ represents the susceptibility of the soil or surface material to erosion, the transportability of the sediment and the amount and runoff rate from a particular rainfall input, measured under normal conditions. The standard condition is the plot of units, $22.6 \mathrm{~m}$ long with a gradient of $9 \%[4]$.

$$
K=0,1317 * f_{\text {csand }} * f_{\text {cl-si }} * f_{\text {orgC }} * f_{\text {hisand }}
$$

where

$$
\begin{aligned}
& f_{\text {csand }}=\left\{0,2+0,3 * \exp \llbracket-0,0256 * m_{\mathrm{s}} *\left(1-\frac{m_{\text {silt }}}{100}\right) \rrbracket\right\} \\
& f_{\text {cl-si }}=\left(\frac{m_{\text {silt }}}{m_{\mathrm{c}}+m_{\text {silt }}}\right)^{0,3} ; \\
& f_{\text {orgC }}=\left[1-\frac{0,25 * \text { orgC }}{\operatorname{orgC}+\exp [3,72-2,95 * \text { orgC }]}\right] ; \\
& f_{\text {hisand }}=\left[1-\frac{0,70 *\left(1-\frac{m_{\mathrm{s}}}{100}\right)}{\left(1-\frac{m_{\mathrm{s}}}{100}\right)+\exp \left[-5,51+22,9 *\left(1+\frac{m_{\mathrm{s}}}{100}\right)\right]}\right]
\end{aligned}
$$

where $m_{\mathrm{s}}, m_{\mathrm{silt}}$ and $m_{\mathrm{c}}$ - the proportion of sand, silt and clay contained in the soil, \%; $\operatorname{org} C$ - organic carbon content.

Topographic Factor $(\boldsymbol{L S})$. The topographic factor represents a relation of soil loss in a given condition to that of an area with a "standard" slope of $9 \%$ slope and a slope length of $22.6 \mathrm{~m}$. The topographical factor constitutes two factors that are the length of the slope $(L)$ and the slope of the slope $(S)$.

$$
L=\left(\frac{\lambda}{22,13}\right)^{m} ; m=\frac{F}{1+F} ; F=\frac{\frac{\sin \beta}{0,0896}}{3 *(\sin \beta)^{0,8}+0,56} \text {. }
$$

The equation used in GIS:

$$
L_{(i, j)}=\frac{\left[A_{(i, j)}+D^{2}\right]^{(m+1)}-A_{(i, j)}^{(m+1)}}{x^{m} * D^{m+2} *(22,13)^{m}},
$$

where $A(i, j)$ is a part of the basin area, pixel; $D$ is the pixel size; $x$ - form correction factor.

The factor $S$ depends on the slopes $\beta$ of the slopes of the basin. Options for determining $\beta[5]$ :

- to $\tan \beta(i, j)<0,09$

$$
S_{(i, j)}=10,8 * \sin \beta_{(i, j)}+0,03 \text {; }
$$


- to $\tan \beta(i, j) \geq 0,09$

$$
S_{(i, j)}=16,8 * \sin \beta_{(i, j)}-0,5 .
$$

Crop management factor $(\boldsymbol{C})$. The $C$-factors are the most important values for crop management. Therefore, the $C$-factors found by [6] were used to indicate the effect of cropping and management practices on soil erosion rates in agricultural lands. The seasonal variation of $C$-factor depends on many factors such as rainfall, agricultural practice, type of crops etc. However, the present study considered an annual variation.

Table 1

Value of the factor $C$ for each land use

\begin{tabular}{|c|c|}
\hline Factor $\boldsymbol{C}$ & Description \\
\hline 0 & Water Bodies \\
\hline 0.2 & Grasslands \\
\hline 0.029 & Shrublands \\
\hline 0.5 & Savannas \\
\hline 0.1 & Evergreen Broadleaf Forests \\
\hline 0.001 & Deciduous Broadleaf Forests \\
\hline 0.0015 & Evergreen Needleleaf Forests \\
\hline 0.0015 & Deciduous Needleleaf Forests \\
\hline 0.002 & Urban and Built-up Lands \\
\hline
\end{tabular}

Conservation Practice Factor $(\boldsymbol{P})$. The conservation practice factor $(P)$ represents the ratio of soil loss by a support practice to that of straight-row farming up and down the slope and is used to account for the positive impacts of those support practices. The value of $P$ factor ranges from 0 to 1 , the value approaching to 0 indicates good conservation practice and the value approaching to 1 indicates poor conservation practice [7].

Thus, $P$ factor value was taken as 1 because the majority of the study area is doesn't have determinate concertation practice. The Food and Agriculture Organization of the United Nations (FAO) classifies water erosion by levels of soil loss from water erosion (Table 2).

The maximum value is given to the feature with highest susceptibility and the minimum being to the lowest susceptible feature.

Classification of water erosion [FAO, 1980]

\begin{tabular}{|c|c|}
\hline Range (T/ha* year) & Erosion condition \\
\hline 0 & Null \\
\hline $0-10$ & Faint \\
\hline $10-50$ & Moderate \\
\hline $50-200$ & Severe \\
\hline$>200$ & very severe \\
\hline
\end{tabular}

\section{Results}

1. Rainfall erosivity factor $(\boldsymbol{R})$. The rainfall erosivity was generated using the models discussed in the methodology of study. The period of 20 average annual rainfall years was taken in. The results showed that in Burundi the $R$ value 
ranges between 938.35 and $435.65 \mathrm{MJ} / \mathrm{ha} \cdot \mathrm{mm} / \mathrm{h}$. The map of rainfall erosivity index $(\mathrm{R})$ derived for the study area is shown in Figure 3.

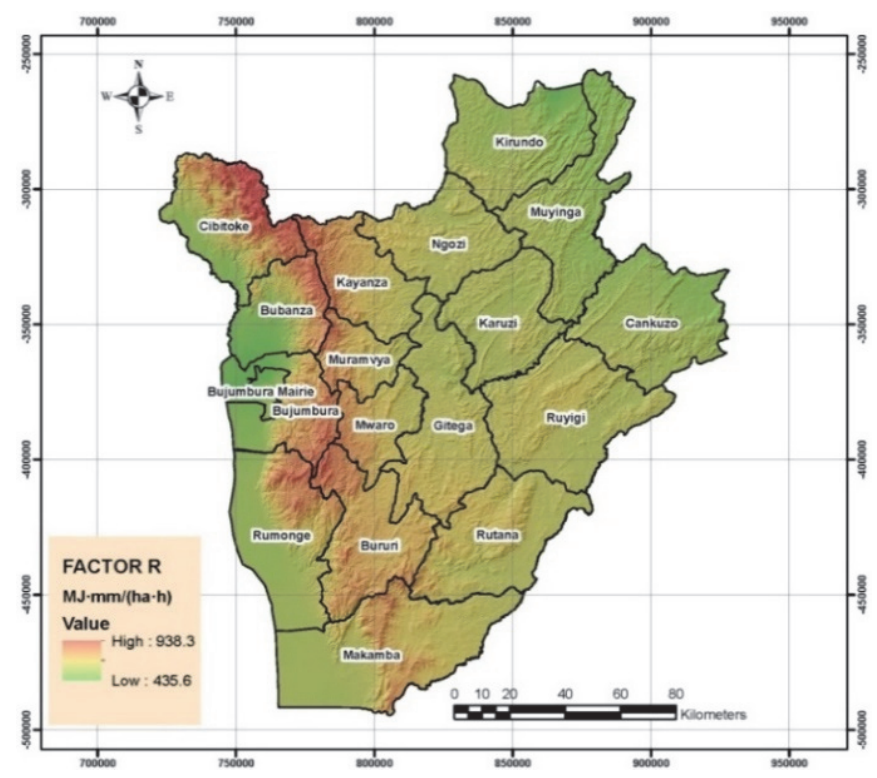

Figure 3. $R$ factor map

2. Soil erodibility factor $(K) . K$ factor values were assigned to respective soil types in soil map to generate the soil erodibility map. The values of $K$ factor are found to be ranging between. It represents both susceptibility of soil to erosion and the rate of runoff as measured under the standard and plot condition. The erodibility index map derived from FAO's soil map of study area is shown on Figure 4. The $k$-values obtained the study area ranged from 0 to 0.00158 . The lower value of $K$ factor is associated with the soils having low permeability, low antecedent moisture content.

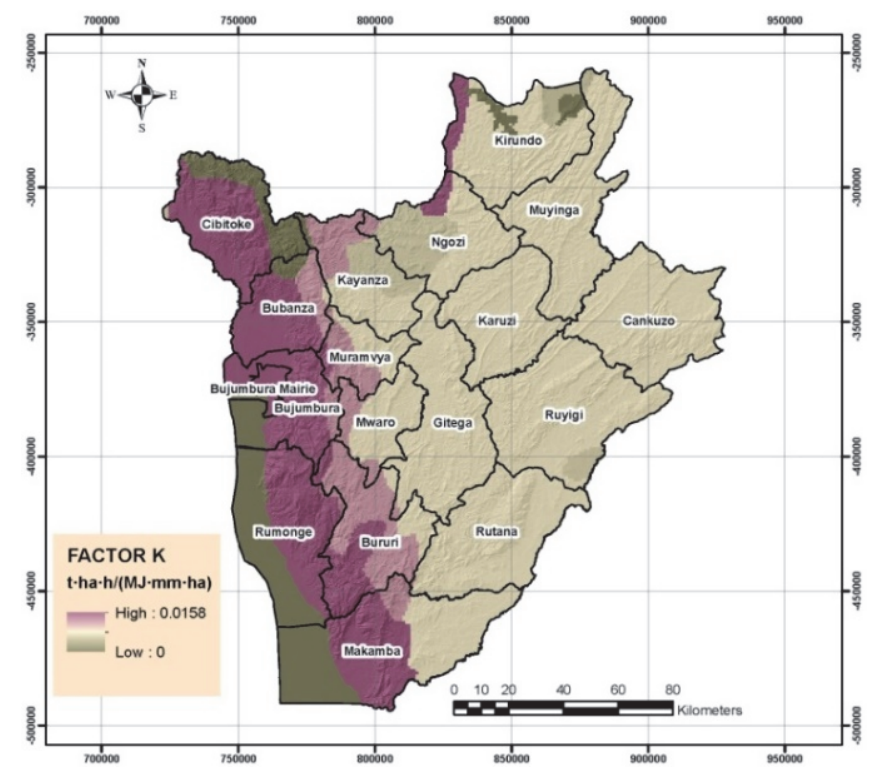

Figure 4. $K$ soil erodibility factor 
3. $\boldsymbol{L S}$ Factor. From Figure 5 it is observed that the minimum value of $L$ is 0.9 and the maximum value is 49.6. For the factor $S$, its minimum value is 0.03 and its maximum value 14.3(Figure 6).

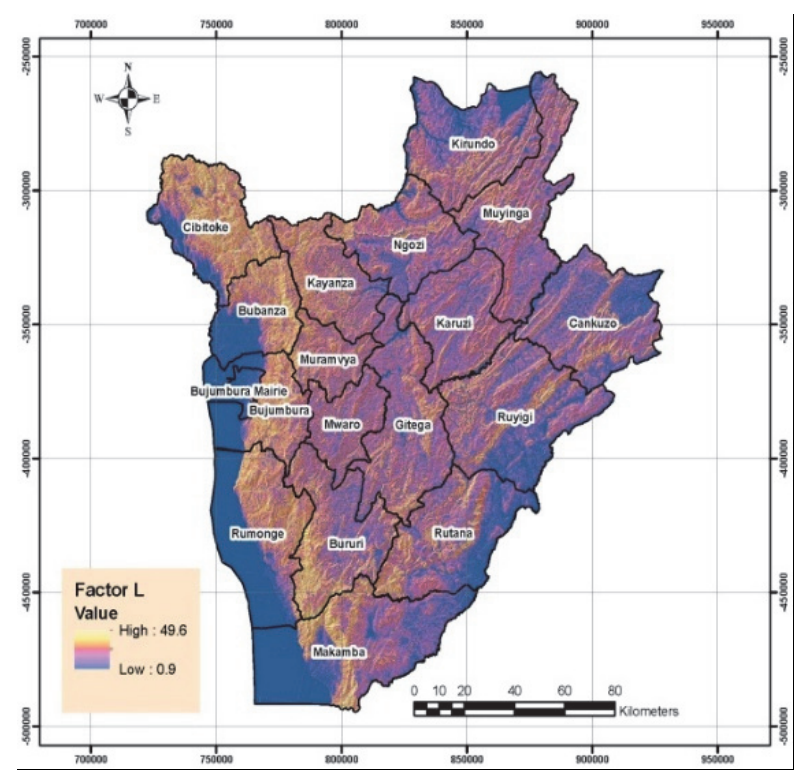

Figure 5. $L$ factor map

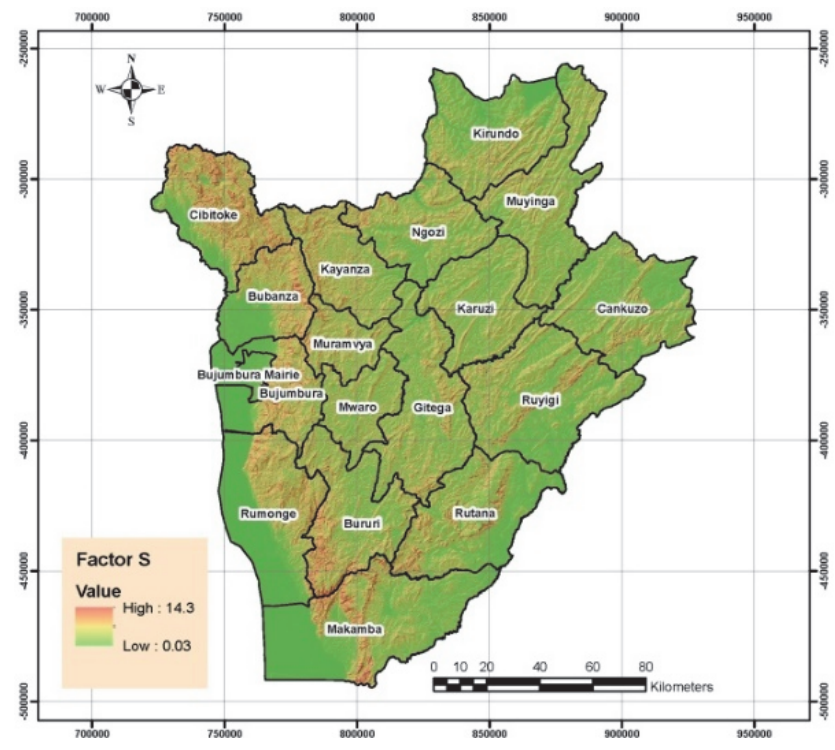

Figure 6. $S$ factor map

4. Crop management factor $(C)$. $C$ factor for land use/cover for our ranges from 0 to 0.5 . The value 0 corresponds to water bodies and 0.5 to a wetland with vegetation. The $C$-factor map for the study area is shown in Figure 7.

5. Rate of Soil Loss. Soil losses in T/ha*year caused by water erosion have been presented as classes. The loss of the soil greater than $200 \mathrm{~T} / \mathrm{ha}$ *year is the most observed throughout the national territory. It followed by the class of 50-200 T/ha*year. The results are shown in Figure 8. 


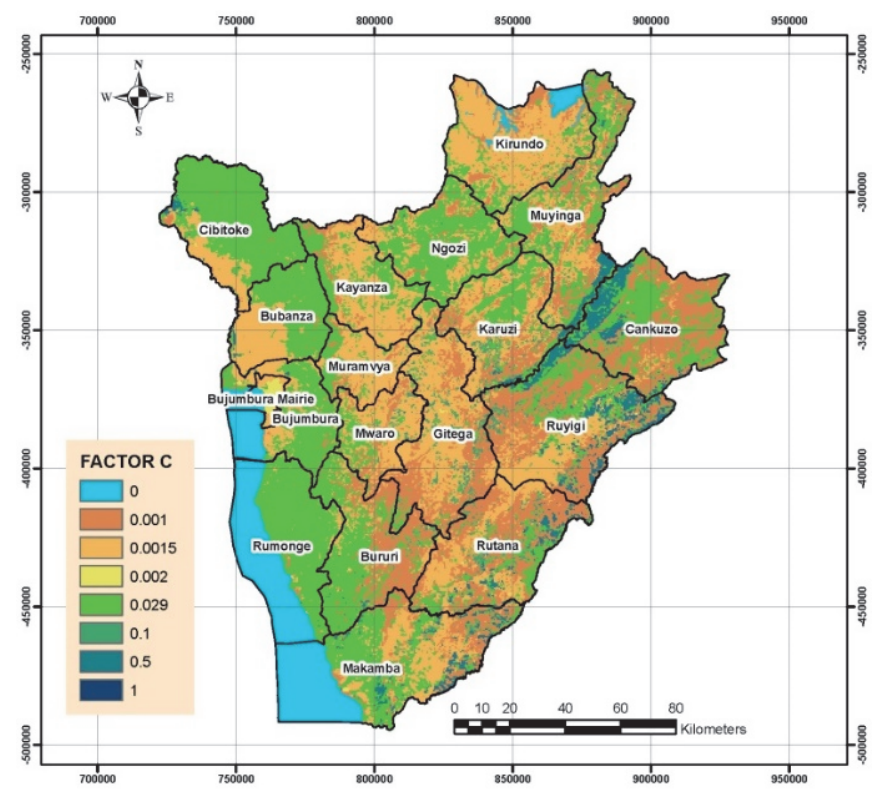

Figure 7. $C$ factor map

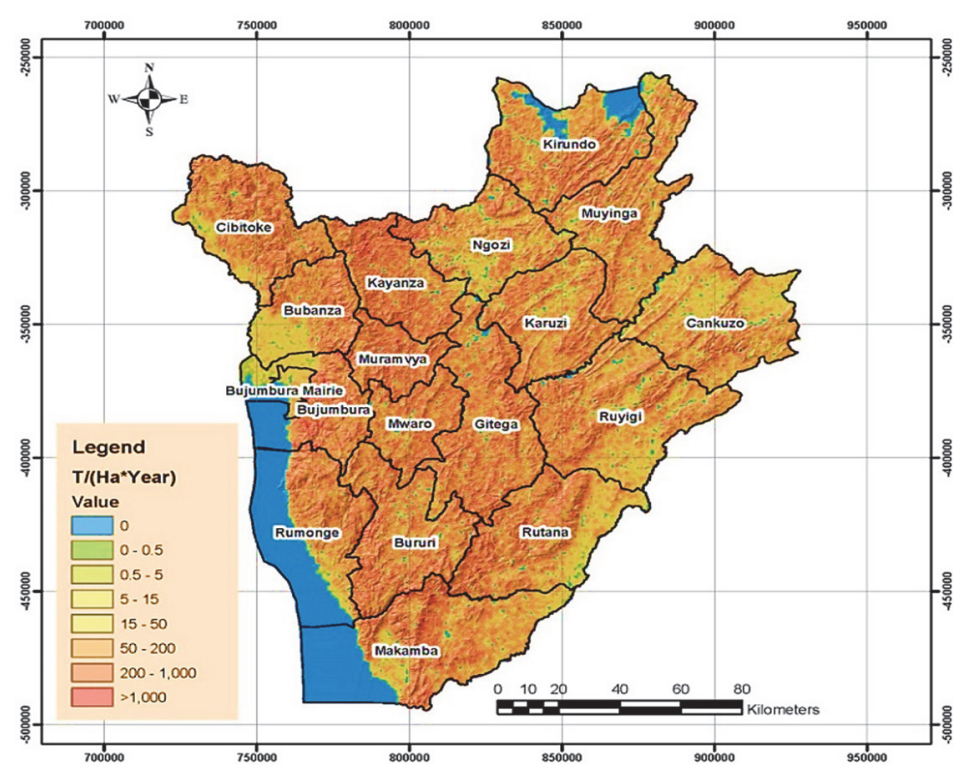

Figure 8. Water erosion map showing soil loss in $\mathrm{T} / \mathrm{ha}^{\star}$ year

The statistical tool of the ArcMap software allowed to give the eroded area according to the losses of soil. This allowed to evaluate the condition of erosion according to the FAO reference data. The results are shown in Table 3.

Area subject to erosion in ha

\begin{tabular}{|c|c|c|c|}
\hline Range (T/ha* year) & Area (Ha) & Erosion condition & Percentage \\
\hline 0 & 251938,9 & Null & 9 \\
\hline $0-10$ & 187580,67 & Faint & 7 \\
\hline $10-50$ & 532819,36 & Moderate & 34 \\
\hline $50-200$ & 925149,45 & Severe & 30 \\
\hline$>200$ & 817035,51 & Very severe & \\
\hline
\end{tabular}


The results show that more than $64 \%$ of the national territory is subject to very severe erosion. Statistical results using ArcMap software tools show that provinces (Muramvya, Kayanza, Mwaro and Gitega) are experiencing huge annual losses per hectare of soil under water erosion (Table 4).

Table 4

Quantification of erosion by province (in T/ha*year)

\begin{tabular}{|c|c|c|c|}
\hline \multicolumn{4}{|c|}{ Erosion Burundi's provinces } \\
\hline Province & (T/ha*year) & Province & (T/ha* year) \\
\hline Bubanza & 147 & Kirundo & 153 \\
\hline Bujumbura Mairie & 37 & Makamba & 146 \\
\hline Bujumbura Rural & 182 & Muramvya & 322 \\
\hline Bururi & 159 & Muyinga & 144 \\
\hline Cankuzo & 94 & Mwaro & 233 \\
\hline Cibitoke & 174 & Ngozi & 150 \\
\hline Gitega & 217 & Rumonge & 93 \\
\hline Karuzi & 156 & Rutana & 197 \\
\hline Kayanza & 312 & Ruyigi & 144 \\
\hline
\end{tabular}

The results show that almost the entire extent of Burundi is experiencing severe erosion according to the FAO classification of water erosion.

\section{Conclusion}

On an area of $27145 \mathrm{~km}^{2}$ (almost the entire national territory) that was the subject of this study using the RUSLE model, $64 \%$ experienced severe erosion.

Depth analyzes show that the soil erodibility factor $(K)$ values are very high for the part of Burundi located in the Imbo plain, the western slope of the CongoNile Ridge, the Congo-Nile Ridge, the neighboring part of the Rwanda in Ngozi and Kirundo provinces in northern Burundi. The lowest values correspond to certain portions located in Kayanza, Ngozi, Kirundo and Ruyigi Provinces.

The minimum values of the $L$ factor (length of the slope) largely represent the depressions of the North East and the Imbo plain in western Burundi. Values for this factor are high for Congo-Nile Ridge.

For the $S$ factor (slope), the large values are observed for the Congo-Nile Ridge region.

The values of the $C$ factor (vegetation cover) show high values for the western slope of the Congo-Nile Ridge, the Congo-Nile Ridge covered largely by the Kibira National Park, clear forests, natural reserves and palm oil plantations. Most of the provinces Ngozi, Muyinga, Karusi are occupied by crops, perennials and afforestation. In the eastern depressions, there are protected landscapes and Ruvubu National Park.

The results for this study show that the $K$ and $C$ factors for this study in no way influence the mechanism of water erosion. The factor $L$ has an influence but is very weak. The $S$ factor has a very significant influence on water erosion in Burundi.

\section{References}

[1] Aquastat. Burundi. Rapp. sur l'eau. 2005;29: 1-10.

[2] Lim KJ, Sagong M, Engel BA, Tang Z, Choi J, Kim KS. GIS-based sediment assessment tool. Catena. 2005;64(1): 61-80. 
[3] Gvozdenovich JJ. Calculo del factor $R$ de la USLE a traves del indice modificacdo de Fournier. 2016(June). p. 9.

[4] Wang B, Zheng F, Guan Y. Improved USLE-K factor prediction: A case study on water erosion areas in China. Int. Soil Water Conserv. Res., 2016;4(3): 168-176.

[5] Ganasri BP, Ramesh H. Assessment of soil erosion by RUSLE model using remote sensing and GIS: A case study of Nethravathi Basin. Geosci. Front. 2016; 7(6): 953-961.

[6] Karaburun A. Estimation of C factor for soil erosion modeling using NDVI in Buyukcekmece watershed. Ozean J. Appl. Sci. 2010;3(1): 77-85.

[7] Kuok KKK, Mah DYS, Chiu PC. Evaluation of C and P Factors in Universal Soil Loss Equation on Trapping Sediment: Case Study of Santubong River. J. Water Resour. Prot. 2013;5(12): 1149-1154.

[8] http://hikersbay.com/climate/burundi?lang=en (Accessed 1 April 2019).

[9] UNECN. 2013 Stratégie Nationale et Plan d'Action sur la Biodiversité 2013-2020. p. 39-45.

[10] Roose EJ. Quelques exemples des effets de l'erosion hydrique sur les cultures. Colloque sur la fertilité des sols tropicaux. Tananarivè 19-25.11.1967. Communication No. 113. 1967. p. 1385-1404.

[11] Rishirumuhirwa T. Facteurs anthropiques de l'érosion dans les régions des montagnes et hauts plateaux de la C.E.P.G.L. (Burundi - Rwanda - Zaïre). Réseau Erosion - Bulletin. 1993;(13): 53-62.

[12] Koffi N, Guillaume A, Vimard P, Zanou B. Maîtrise de la croissance démographique et développement en Afrique (Colloques et Séminaires). Paris: ORSTOM; 1994: 381-402.

[13] Laflen JM, Roose EJ. Methodologies for assessment of soil degradation due to water erosion. USA: CRC Press LLC; 1997.

[14] Arnoldus HMJ. Methodology used to determine the maximum average soil loss due to sheet and rill erosion in Morocco. Soils Bulletin FAO. 1980;34: 39-48.

\section{Article history:}

Received: 03.04.2019

Revised: 20.06.2019

\section{For citation:}

Nijimbere G, Riveros Lizana C. Assessment of soil erosion of Burundi using remote sensing and GIS by RUSLE model. RUDN Journal of Ecology and Life Safety. 2019;27(1): 17-28. http://dx.doi.org/10.22363/2313-2310-2019-27-1-17-28

\section{Bio notes:}

Gilbert Nijimbere- M.Sc in Environmental Sciences, PhD student, Department of Breeding, Genetics and Seed Production, Faculty of Agronomy and Ecology, Kuban State Agrarian University named after I.T. Trubilin. Contact information: e-mail: gilbertnijimbere83@gmail.com

Christian Riveros Lizana - master student, Department of Hydraulics and Agricultural Water Supply, Faculty of Hydroamelioration, Kuban State Agrarian University named after I.T. Trubilin. Contact information: e-mail: 20110337@1amolina.edu.pe 
Научная статья

\title{
Оценка эрозии почвы Бурунди \\ с использованием дистанционного зондирования и ГИС по модели РУСЛЕ
}

\author{
Г. Нижимбере, К. Риверос Лизана \\ Кубанский государственный аграрный университет имени И.Т. Трубилина \\ Российская Федерация, 350044, Краснодар, ул. Калинина, 13
}

\begin{abstract}
Аннотация. Настоящая статья посвящена результатам исследований по водной эрозии в Бурунди - стране, не имеющей выхода к морю, в районе африканских Великих озер, где сходятся Восточная и Центральная Африка. Сельское хозяйство развито в районах, где склоны очень крутые, а некоторые факторы, например методы землепользования, ослабляют почву и приводят к водной эрозии, что влечет за собой деградацию почвы и делает ее бесплодной. Производство по этому пути становится недостаточным для быстро растущего населения. Расширение обрабатываемой земли, часто не связанное с противоэрозионными мерами, подвергает почву интенсивной эрозии. Данные обработки спутниковых снимков (Landsat 8) позволили выявить основные места, где эрозия очень сильная. Потерянная почва оценивалась по методу РУСЛЕ и с использованием четырех растровых изображений, соответствующих факторам, связанным с осадками, разрушаемостью почвы, топографией, длиной склона и растительным покровом. Полученные результаты позволяют определить районы по всей стране, где необходимо вмешательство правительства и природоохранных учреждений для ограничения процессов деградации почвы.
\end{abstract}

Ключевые слова: Бурунди; эрозия почв; землепользование; РУСЛЕ; деградация почв; классификация почв; защита сельского хозяйства

\section{Список литературы}

[1] Aquastat. Burundi // Rapp. sur l'eau. 2005. Vol. 29. Pp. 1-10.

[2] Lim K.J., Sagong M., Engel B.A., Tang Z., Choi J., Kim K.S. GIS-based sediment assessment tool // Catena. 2005. Vol. 64. No. 1. Pp. 61-80.

[3] Gvozdenovich J.J. Calculo del factor R de la USLE a traves del indice modificacdo de Fournier. June 2016. P. 9.

[4] Wang B., Zheng F., Guan Y. Improved USLE-K factor prediction: A case study on water erosion areas in China // Int. Soil Water Conserv. Res. 2016. Vol. 4. No. 3. Pp. 168-176.

[5] Ganasri B.P., Ramesh H. Assessment of soil erosion by RUSLE model using remote sensing and GIS: A case study of Nethravathi Basin // Geosci. Front. 2016. Vol. 7. No. 6. Pp. 953-961.

[6] Karaburun A. Estimation of C factor for soil erosion modeling using NDVI in Buyukcekmece watershed // Ozean J. Appl. Sci. 2010. Vol. 3. No. 1. Pp. 77-85.

[7] Kuok K.K.K., Mah D.Y.S., Chiu P.C. Evaluation of C and P Factors in Universal Soil Loss Equation on Trapping Sediment: Case Study of Santubong River // J. Water Resour. Prot. 2013. Vol. 5. No. 12. Pp. 1149-1154.

[8] URL: http://hikersbay.com/climate/burundi?lang=en (дата обращения: 01.04.2019).

[9] UNECN. 2013 Stratégie Nationale et Plan d'Action sur la Biodiversité 2013-2020. Pp. 39-45. 
[10] Roose E.J. Quelques exemples des effets de l'erosion hydrique sur les cultures // Colloque sur la fertilité des sols tropicaux. Tananarivè 19-25.11.1967. Communication No. 113. 1967. Pp. 1385-1404.

[11] Rishirumuhirwa T. Facteurs anthropiques de l'érosion dans les régions des montagnes et hauts plateaux de la C.E.P.G.L. (Burundi - Rwanda - Zaïre) // Réseau Erosion Bulletin. 1993. No. 13. Pp. 53-62.

[12] Koffi N., Guillaume A., Vimard P., Zanou B. Maîtrise de la croissance démographique et développement en Afrique (Colloques et Séminaires). Paris: ORSTOM, 1994. Pp. 381-402.

[13] Laflen J.M., Roose E.J. Methodologies for assessment of soil degradation due to water erosion. USA: CRC Press LLC, 1997.

[14] Arnoldus H.M.J. Methodology used to determine the maximum average soil loss due to sheet and rill erosion in Morocco // Soils Bulletin FAO. 1980. Vol. 34. Pp. 39-48.

\section{История статьи:}

Дата поступления в редакцию: 03.04.2019

Дата принятия к печати: 20.06.2019

\section{Для цитирования:}

Nijimbere G., Riveros Lizana C. Assessment of soil erosion of Burundi using remote sensing and GIS by RUSLE model (Оценка эрозии почвы Бурунди с использованием дистанционного зондирования и ГИС по модели РУСЛЕ) // Вестник Российского университета дружбы народов. Серия: Экология и безопасность жизнедеятельности. 2019. Т. 27. № 1. С. 17-28. http://dx.doi.org/10.22363/2313-2310-2019-27-1-17-28

\section{Сведения об авторах:}

Нижимбере Гилберт - аспирант, кафедра селекции, генетики и семеноводства, факультет агрономии и экологии, Кубанский государственный аграрный университет имени И.Т. Трубилина. Контактная информация: e-mail: gilbertnijimbere83@gmail.com

Риверос Лизана Кристиан - магистр, кафедра гидравлики и сельскохозяйственного водоснабжения, факультет гидромелиорации, Кубанский государственный аграрный университет имени И.Т. Трубилина. Контактная информация: e-mail: 20110337@ lamolina.edu.pe 